\title{
14
}

\section{Sir James Plimsoll: Mandarin Abroad}

\author{
Jeremy Hearder ${ }^{1}$
}

James Plimsoll's life and career had similarities with others featured in this volume, but also significant differences. The main difference was that for two-thirds of his time he was abroad. Dwarfs and mandarins succeeded in part because they had effective communication with the ministers for whom they worked; that is, mutual comprehension, trust and respect. For the mandarin based abroad this was more difficult, given distance, poor communications, and being less aware of the atmospherics at home. Provision of frank and fearless advice was hard from afar, when such advice clearly was not going to be well received and even harder when you do not personally know the minister or Snow White. So the ideal was for the ambassador to feel confident in knowing Snow White's mind, and for Snow White to have personal confidence in the ambassador.

Let me tell you a true fairy story. Once upon a time, in 1962, Snow White decided to go to New York without any of the dwarfs, because Snow White knew he would be well looked after by that mandarin over there, Plimsoll. In New York, Snow White found that Plimsoll kept on trying to bring up the subject of Rhodesia. An increasingly prominent and sensitive issue, it had been inscribed as an agenda item to be debated in the United Nations General Assembly in a few days time. Plimsoll was getting no guidance from officials in Canberra on what he should say. Snow White kept fobbing him off. Eventually, when Snow White was about to board a plane to return home, Plimsoll implored him once again for guidance about what he should say about Rhodesia. Snow White clapped him on the shoulder and said: 'My boy, I'm glad you're making [the speech], not me', and climbed aboard. Plimsoll took it that he could say what he wanted to. ${ }^{2}$

That sort of latitude extended to a diplomat abroad is rare. Menzies knew what he was doing. Plimsoll was someone whose judgment he had come to respect during Plimsoll's earlier six years in Canberra. Menzies knew that during the

\footnotetext{
1 The following is based on the author's research for his book Jim Plim Ambassador Extraordinary: A Biography of Sir James Plimsoll (Ballarat, VIC: Connor Court Publishing, 2015).

2 James Plimsoll in conversation with Clyde R. Cameron (1984), National Library of Australia, nla.ohvn677900, transcript, Vol. ii, 6-7.
} 
past three years Plimsoll's duties had taken him on three extensive visits through Africa - in those days he had seen more than most of the Unknown Continent. More recently, Menzies had approved of the way that Plimsoll, in transiting London, had handled an unexpected meeting with the British Secretary of State for Colonies, Duncan Sandys, at Sandys' request. Sandys had told Plimsoll that the United Kingdom intended to make Rhodesia independent soon. To Sandys' chagrin, Plimsoll had quoted the relevant passage from the United Nations Charter to him and said he doubted that Australia would agree to the grant of independence to a minority government. ${ }^{3}$ Menzies had also approved other things Plimsoll had done at the United Nations when unable to get instructions in time. ${ }^{4}$ With no other prime minister did Plimsoll enjoy such a close working relationship.

Years later, in 1974, Plimsoll called on Menzies in retirement, days after the announcement of the new governor-general, Sir John Kerr. Menzies said he thought this appointment was a mistake, without saying why. If he had still been in office, he would have recommended Plimsoll for the post - but that is another story. ${ }^{5}$

For nearly 35 years, Jim Plimsoll was one of Australia's leading diplomats. He had an exceptional career. He was secretary of the Department of External Affairs in Canberra from 1965 to 1970. He served as ambassador no less than eight times, all in places of major importance to Australia - Korea, the United Nations in New York, New Delhi, Washington, Moscow, Brussels, London, and Tokyo.

Unlike other dwarfs and mandarins, Plimsoll spent only one-third of his career in Canberra. He was posted abroad for the remainder. He tolerated rather than liked living in Canberra, and bought no real estate. Canberra was all about the job, not a home. It was only the personal persuasion of Dr Evatt, the then minister for External Affairs, that led him to come to Canberra and join the department in the first place in 1948. His ambitions did not lie in power, or management of a large organisation. This was 'not his cup of tea'. ${ }^{6}$

Plimsoll was passionate about the task of representing Australia abroad. He declined offers to take high level posts in the Secretariat of the United Nations, at twice the pay. After reaching the pinnacle, first as secretary then as ambassador in Washington, when he could have gone into other things, he stayed on as a diplomat. Instead, he accepted posts of slightly lower status - indeed, he wanted to be first high commissioner in Papua New Guinea.

Ibid., 5-6.

See Menzies' reply to a parliamentary question from Dr J.F. Cairns on 17 October 1961. Current Notes on

International Affairs, 32, no. 10 (October 1961), 54-7.

5 Plimsoll in conversation, 377.

6 Sir Garfield Barwick, conversation with author, December 1996. 


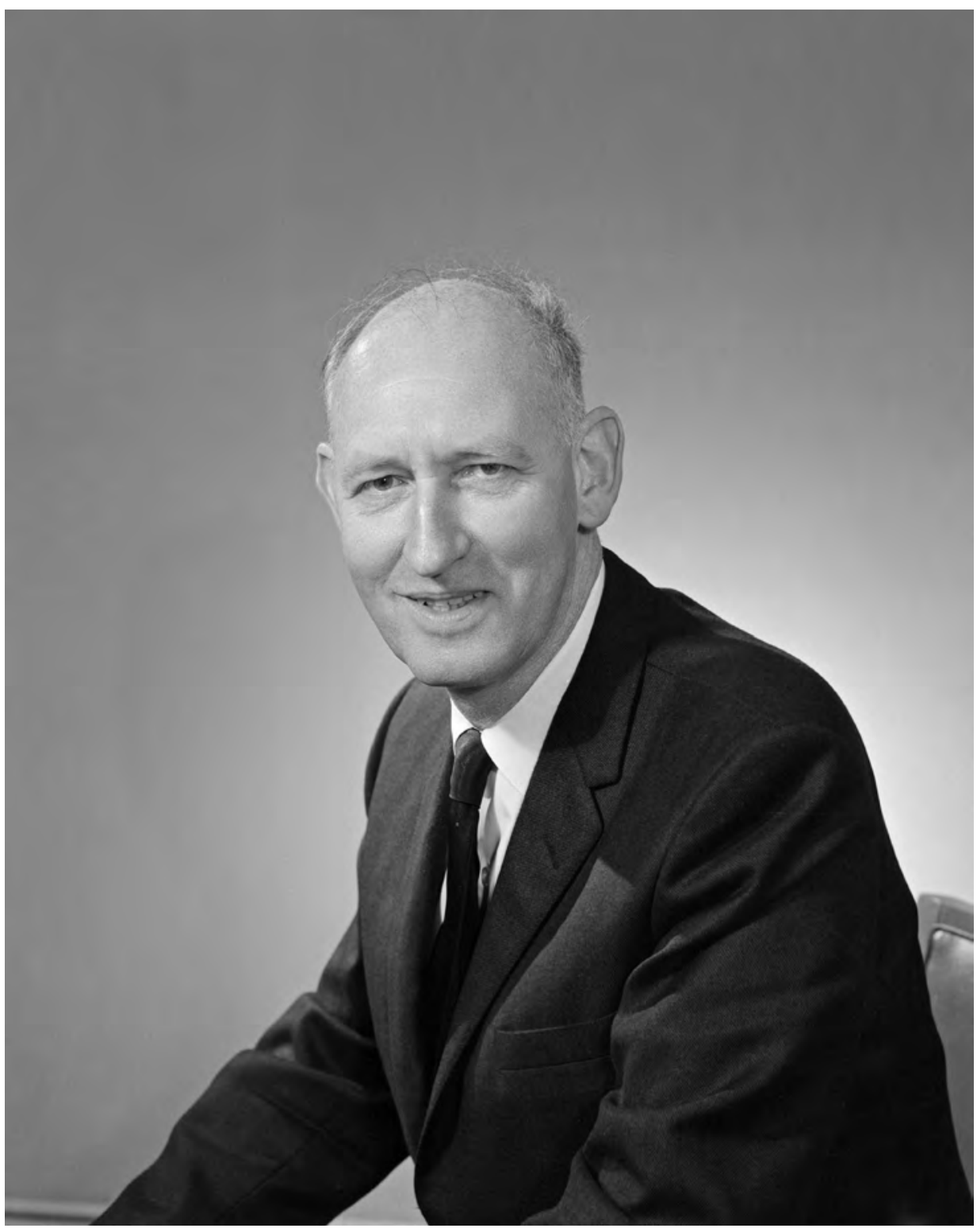

Sir James Plimsoll, 1965

Source: National Archives of Australia, A1200, L52865 
Plimsoll's upbringing was similar to a number of the other dwarfs and mandarins - attendance at a leading selective state school, and an economics degree as an evening student. But there were some differences. Over the next few years, Plimsoll went through further education and an unusually stimulating onthe-job training in research, analysis, communication and representation. He remained at Sydney University for eight years, during which he added an arts degree, had extensive debating experience in the University Union, and was elected president of the Union. By day he worked in the Research Department of the Bank of New South Wales, the first of its kind in Australia. In order to accomplish all this, he developed an almost monastic approach to living. Work came first, an approach he never lost. His father could have paid for fulltime university study, yet with an accountant's caution after the Depression he insisted Plimsoll get a job and study in the evening. During the Second World War, as a captain, he worked with Alf Conlon, a fellow Sydney student politician, in the Directorate of Army Research in Melbourne, with all those often brilliant, eccentric colleagues. In 1945 he went to the United States to attend a school in military government. Out of 350 students, mainly American, British and Canadian officers, he came second. Then, as Major Plimsoll, he was Australia's representative on the Far Eastern Commission in Washington. Other differences were that he remained single, and although the youngest of the dwarfs/mandarins, he died the earliest, except for Crawford - I think due to overwork.

As a diplomat, Plimsoll developed a standing that made key foreigners not only happy to see him, but sometimes want to seek him out to discuss their own problems. In Korea during the Korean War, Plimsoll at age 33, and with very limited experience, had President Syngman Rhee, a much older man, often ask his advice. Plimsoll so impressed the Americans that when he was transferred to Canberra, the Americans, most unusually, requested Australia to send him back, which it did. In Washington in 1973, during a particularly difficult time when the newly elected Whitlam Government's foreign policy approach enraged President Nixon, the Australian Embassy had its normal access to the US Administration frozen. But the US Secretary of State, William Rogers, and his senior people, as well as other members of the Administration, openly flouted this prohibition, such was their desire to maintain communication with Plimsoll. In Moscow in 1977, a group of very senior officials of the Foreign Ministry called Plimsoll in to seek his personal advice about how the Soviet Union should react to Indira Gandhi's shock loss in the Indian elections, which had just occurred. His access to key people enhanced the value of the reports that he sent home - brief, clear, timely. They were closely read at all levels.

It was a great disappointment to Plimsoll that Menzies retired within a year of his becoming secretary in Canberra. Although on good terms with Holt and 
then Gorton, privately he was critical of both. Like others, he was contemptuous of McMahon. With the election of Whitlam, Plimsoll hoped for better things. He had known Whitlam and his wife for some time. His hopes were quickly dashed. It was the immaturity of style in foreign policy; and early on Plimsoll detected Whitlam's ignorance and lack of interest in economic policy. But they remained friends. Plimsoll and Fraser did not know each other well. Fraser was critical of Plimsoll's views about the Soviet Union. When Plimsoll became the first career officer to be high commissioner in London, after only six months Fraser announced that a politician would take his place.

Another way in which Plimsoll differed from the dwarfs and mandarins was in public relations. In those days dwarfs and mandarins were self-effacing, in the background. They rarely if ever uttered a word in public; public relations was up to the minister. Plimsoll was cast in that mould, but with a difference. He was ahead of his time as a public servant who was a confident communicator, who understood the importance of public relations, and was prepared to talk to journalists. When secretary of the department in November 1965 he gave the Norman Smith Memorial lecture on journalism at Melbourne University about Asian issues and the press; he appeared in a television documentary on the department; and, visiting Delhi in 1967, he appeared with his Indian counterpart in a press conference after annual official talks with the Indians. That Paul Hasluck, who as minister was hostile to the very existence of the media section of the department, was prepared to countenance the secretary engaging in these activities underlined his trust in Plimsoll. Plimsoll substantially ghostwrote two books by ministers he served, one by Dr Evatt in 1949, The Task of Nations, ${ }^{7}$ and one in 1954 by Casey, Friends and Neighbours. ${ }^{8}$ The first was about the United Nations by Evatt in his capacity as President of the United Nations General Assembly. Plimsoll, based in New York, also conducted negotiations on behalf of Evatt with the US publisher, compiled the index and checked the proofs. The second by Casey emphasised the importance of the Asian region to Australia.

Plimsoll had the usual attributes of a good diplomat, although to this should be added that he worked exceptionally hard, was endlessly curious, had a photographic memory, and was always very well informed on a wide variety of issues. And he had a certain gravitas in his bearing, partly because he looked older than he really was, which was helpful in his thirties and forties when dealing, as he frequently had to, with people who were 20 or more years older. On the other hand he was very private, upright, and socially conservative; and, while approachable, he often had difficulty with small talk. He was somewhat unworldly, and absentminded about details of daily living, such as depositing

7 H.V. Evatt, The Task of Nations (New York: Duell, Sloan and Pearce, 1949).

8 R.G. Casey, Friends and Neighbours: Australia and the World (Melbourne: Cheshire, 1954). 
cheques that he received. His monastic, simple way of living, owning neither property nor car, often only one suit, did not change, like his absorption in his work. Plimsoll approved of the following description of John Crawford: 'a very intense man who lived his work day and night, and was always thinking when he was walking around. ${ }^{9}$ The description fits Plimsoll also.

When he had time, Plimsoll's main interests outside work were art, literature and music, in all of which he had considerable knowledge that he was sometimes able to deploy to advantage in his work. In art, while secretary of the department, he served on the interim committee of the National Gallery of Australia. In Moscow, he made a special personal contribution to fostering cultural relations. At Moscow State University he befriended the professor and dean of English and, at her invitation, he delivered a seminar a week for six months to graduate students and faculty members on various kinds of literature - English, Australian, American, other Commonwealth - also on punctuation and grammar. The dean was a strong personality, and she was of sufficient clout in the Communist Party to override objections to a Western ambassador lecturing the cream of Russian students during the Cold War.

Plimsoll was a major figure in what was an early, formative period in Australian foreign policy. He made a major contribution towards a greater realisation of the importance of Asian countries, notably India - about which he was ahead of his time in trying to raise interest. He was a considerable figure in the relationship with the United States. On the other hand, he held considerable reservations about China. Abroad, the post-war period was a time when Australia was a middle ranking country that had only recently found its voice in international affairs, but was little known. Filling this void was a task for many, but Plimsoll contributed significantly because of his stature and that he was so widely respected. Diplomacy was a little known profession in Australia when Plimsoll started during the 1940s. He helped set standards and style. At home he was in the vanguard in making Australian ministers and prime ministers come to realise the value to them of this new professional foreign service.

9 Plimsoll in conversation, 16 
This text is taken from The Seven Dwarfs and the Age of the Mandarins: Australian Government Administration in the Post-War Reconstruction Era, edited by Samuel Furphy, published 2015 by ANU Press, The Australian National University, Canberra, Australia. 